\title{
Adoption History. \\ From Ancient Societies to Contemporary Societies
}

\author{
Silvia Timofti \\ Faculty of Economic Sciences and Public Administration, Law specialization from Suceava, Romania \\ Master in Administration and Formation of Human Resources in Organizations at "Ștefan cel Mare" University of \\ Suceava,Romania, timoftisilvia@yahoo.com
}

\begin{abstract}
From the earliest times, the religious factor has said its word on several social systems. The social factor has been of great importance and relevance to the social construction of the communities as well as to the regulation of the various institutions I have chosen the ones that represent the interests of society. Among these institution is adoption, being one of the oldest law institutions. Adoption is a social phenomenon that has undergone changes that have been inevitable and a breakthrough in the turn of the century. This form of social protection of children, adoption, played a particularly important role in antiquity especially in the institutions of the Jews, the Assyrians, the Greeks, the Indians and the Romans, because the adopted person was perceived as the one to represent the perpetuation of the religious and political interests of the people, after the persons who approached the children died.
\end{abstract}

KEYWORDS: adoption, adrogation, family, the system of adoption, social protection

\section{Introduction}

It should be noted that in Ancient Greece, adoption was recognized as an institution of public law. Referring to the Indian people, the conditions, forms and effects of adoption were governed by the law, Manu. Manu, speaking of adoption, said: "Whose nature did not give him a son, he may adopt, that the ordinances of the ceremonies may not cease", that the begotten may be the brother's child. Adoption of the Indians in antiquity had a profound interest and cultic utility, that is, it was very important that the people do not quit disappearing, but that someone should be left behind to take care of the funeral ceremonies and the domineering cult.

In the Older Jews, the form of adoption was met by considering that the child of the deceased brother was like his own child, following the marriage of the levirate (Explicative Dictionary of the Romanian Language: levitating to the Jews and other ancient peoples that compelled the brother of a deceased to marry her widow with no child. The appropriate legal practice (with the widow of the deceased brother).

By questioning the primitive people, we can note that the adoption was accompanied by various ceremonies, which consist of a preterm birth, a leak to the chest, to the finger, or a mixture of the adopter's blood with the adopter, so that the acquisition a son to be as close and closer as possible.

In Muslims, adoption is of a particular nature, taking into account the tutelage with which it is confused. In the holy martyrdom of Muslims, the Qur'an says: "God gave man one heart; return your sons who are adoptive to their father, for he loves God. If you do not know the authors of their days, religion urges you to love them as brothers as your relatives" (Grigore 2009, 1). Currently, among Muslim countries, only Tunisia accepts adoption. The necessity and importance of adopting a law to regulate and establish the legal status of adoption arose from some quite tragic events in that country in the winter of 1955-1956, when a lot of poor children were on the street in the to die of hunger, without being able to find a necessary aphorism at the moment (Mihăilă 2010, 18).

In Roman Law, the end of marriage was intended to ensure that the head of the family descended to ensure the perpetuation of his name and to conceal after his death the administration of the goods. But if the head of the family had no descendants, it remained the only opportunity to create some "artificials" on the path of adoption, which established between him and another foreign person similar relations with those on which marriage produced between his parent and his descendants. 


\section{The importance of adopting the adoption of the Romanians}

The essence and importance of the establishment of the Adoption in the Romanian Law constituted its political and religious interests. For the Romans it was very important that the name of their people be carried forward so that it never ceases. Thus, if someone died without having male children, one of the branches of the family salsa was also extinguished. During the very highest magistrate was the Consulate, which only the patricians could have. Through the adoption process, the plebeans were offered among the only means of assisting the Consulate, if adopted by the patricians, and the patricians could become the people's tribune if adopted by the plebeians. One important thing was that adoption provided and guaranteed succession to the throne of the country, when the emperors had no legitimate children. For example: Octaviano, Nero, Traian, Justinian, they were adopted (Mihăilă 2010, 19-20).

The adoption regulations of the Romanian legislation remain the most representative and important in the ancient era, deserving to be researched and analyzed, because the early Romanian legislation in the field of adoption, along with the traditions and customs of the other nations, could be a good example of the implication and significance of the religious in today's adoption system.

Adoption is a solemn act by which a Roman citizen wins the parental power over an alien juror (people submissive to others people). It is accomplished through a rather complicated procedure consisting of a separate sale to a third party, followed by an injured loss in favor of the adopter, which is reduced, in Justinian's time, to a simple statement made to the authorities before the adopter. Also, the express consent of the child was not required, it was sufficient to be present and not to oppose. The adopter acquires succession rights in his new family but continues to retain some funeral rights in the home family as well. The adoption/seniority act was viewed as a charity for a single child who came from a family who could not offer him a good shooter, but this is seen as a glamorous experience to be a parent.

\section{Adoption in the old Romanian law}

The establishment of admission continued to exist in the Middle Ages, especially by taking over the provisions of Roman law. In the former countries of Romania, a number of institutions and rules also concerned the legal condition of illegitimate and legitimate children. The one who has been told about the situation of the child born of marriage was the adopted child. For the admission process, there is no need for unpaired children from the marriage, but often this institution concerned children born out of wedlock. The terminology of the legal institution of the adoption was quite varied, meeting the term "adoption", along with the "adoption", "sentiment", "jokes", "child of soul", " body" .

In the old Romanian law, the choice was more related to humanitarian considerations / arguments, stemming from the necessity of the moral of ensuring and respecting the protection of the children left without family with relatives to care for them, being little conditional the affective solidarity of being between the child and his future parents, or the assurance of material and financial continuity of the family. Thus, these examples are presented above, the following information, dated February 13, 1664, in a letter of consent from Sina de Mare of Mihail Apafi, Matei Gergely, "adopted as a son, under certain conditions, for all his movable and buildings from the Odorhei chair, Ştefan Biro ... " (Mihăilă 2010, 18).

The frequency of adoption in moral needs is explained by the modest and simple condition of the peasant population of the Middle Ages, due to the low interest in securing and guaranteeing the continuity of the winning possession, which is why in the psychology and mentality of the Romanian population the adoption appeared as a condition/explaining both the tendency not to adopt and the retention of mercy towards the admitted child.

A very important aspect was that between the adopted and the adopter there was an age gap, which was not specific, which varied from one legal regime to another. Adoption assimilated or acquired it with very few explanations, the one adopted with the legitimate one. In the development and continuous evolution of the institution, two types of adoption are known, namely adoption filialis and adoption fraternalis. 
1. Adoptio Filialis was the adoption for the realization of legal relationships of filiation (imitation naturae) and was the type of adoption known to us.

2. Adoptio fraternalis is the fraternal adoption with the main purpose of establishing and forming as a brother the adopted one, corresponding to some extent to an original institution of the old Romanian law, the adoption, which in fact consists in the fact that besides Individual twinning also met with twinning, as was the case with children who were twinning, forming the family group of children.

It should also be noted that the adoption of the soul was a real form of completeness of the filiation, which was more common in the Middle Ages, when the number of children was larger, but still possible not only in the churches of lacking heirs, but also for humanitarian reasons, which constituted and represented, one of the old features of a Romanian patriarchal family that distinguished it from that of the peoples.

In the communal system, the adoption is done with the consent of the parents ("to give up", "take heart", the child necessarily acquire the family name of the infetter, and have full rights with his family as his own children, without losing the dominant and upper class also uses preponderance in order to ensure the continuity of goods.

In the written law, snatching was considered "as taking someone as a son, outside marriage".

Enhancing the law fixes the rights of adoptive children that are the same as legitimate children. As a rule, the one who was born was a relative of families of children who were more or poor, but they could also be foreigners, but in rare cases. Parental power was exercised just as with legitimate children, and the obligations and duties of the children were also the same; for example, if there was only one heir, the duty to deal with and the needs of the soul of the deceased deceiver.

Similarly, as a structure and subsequent purpose with the adoption of Wallachia and Moldavia, the adoption is recorded in numerous Transylvanian feudal sources, such as the texts of laws, documents and acts that also specify some particular aspects of it.

The regulations regarding the adoption of the Romanian legislation remain the most representative and important ones of the ancient period, deserving to be investigated and analyzed in more depth, because they were also the basis of the early Romanian legislation in the field of adoption and, along with the traditions of the other ancient societies. It could also be a good example of the greater involvement and significance of the religious factor in today's adoption.

Adoption, which was reserved only to Roman citizens, as the only ones entitled to hold the paternal power within the Roman Empire, was of two types: the actual adoption and adoption (Grigore 2009). Is very important to mention the differents between adrogation and adoption.

The term of adrogation comes from ad and begging, after the three questions asked to the adrogant, the surrogate and the people, through which the adrogation is validated. By adultery, the new member entered the new family there he borrowed the name and god of the adoptive family. In the beginning, the approval of the Pontifical College and the approval of the people by a curated law were required for the execution of the abrogation. The addict was supposed to be 60 years old. Also, he had to be male, to be a parent, not to have children and no hope of having, to be sui juris (the person sui juris, in the Roman acceptance, is the independent person, who is not subject to anyone and self-mastery) and capable.

The actual adoption was a solemn act whereby a Roman citizen gained parental power over an alien juris person (persons subject to others). It was carried out through a complicated procedure, recorded in the Law of the XII Tables, and consisted of a complete sale to a third party, followed by a jure cessio in favor of the adopter, which was reduced, in the time of Justinian, to a simple declaration made before the authorities by the adopter. Also, the child's express consent was not required, it was enough to be present and not to oppose. The adoptee acquired inheritance rights in his new family, but continued to retain some inheritance rights in the family of origin (Grigore 2009, 1). 


\section{Conclusions}

The importance of the institution of adoption has undergone many changes over the years and is also identified in many peoples. These peoples have tried to improve the adoption system and create a healthy society. Building a healthy and prosperous society is based on its basic institution - the family. The laws, laws and policies enforced throughout the centuries have demonstrated that adoption is an instrument used to complete the family and build societies (Irinescu 2009).

In conclusion adoption is a way that gives the child whose parents are unwilling or unable to care for him, or are not suitable for the roll of parents, the opportunity to live in a family environment, generates strong feeling and debate, being influenced ongoing social changes and also it is a big support for children for all life (Irinescu 2009, 20).

\section{References}

Grigore, Tamara. 2009. „Adoption in Ancient Societies.” Lumina Newspaper. Available at https://ziarullumina.ro/documentar/adoptia-in-societatile-antice-41761.html.

Irinescu, Lucia. 2009. Reflections on the institution of adoption. Iași: Scientific Annals Of The "Al.I.Cuza" University Iași. Tomul LV, Legal Sciences. Available at https://laws.uaic.ro/files/docs/articole/2009/Anale2009 art03LuciaIrinescuReflectiiPrivindInstitutiaAdoptiei.pdf.

Mihăilă Oana. 2010. Adoption Romanian and comparative law. Bucharest: Universul Juridic Publishing House. 